\title{
MECANISMOS DE RETIRADA FORÇADA DO ESTRANGEIRO DO TERRITÓRIO NACIONAL: A FAMÍLIA COMO CAUSA IMPEDITIVA DA EXPULSÃO
}

\author{
MECHANISMS OF FORCED WITHDRAWAL OF FOREIGNER \\ FROM NATIONAL TERRITORY: THE FAMILY AS AN \\ IMPEDITIVE CAUSE OF EXPULSION
}

Leonardo Chaves de Carvalho Mestrando em Direito pela Faculdade de Direito da Universidade Federal de Mato Grosso do Sul (UFMS). Pós-graduado em Educação em Direitos Humanos pela Faculdade de Direito da UFMS e em Direito do Trabalho e Processo do Trabalho pela Ematra/MS. Bacharel em Direito pela UFMS. Servidor técnico-administrativo da UFMS/Câmpus de Paranaíba.

Ana Paula Martins Amaral Professora Adjunta da Faculdade de Direito da Universidade Federal de Mato Grosso do Sul UFMS. Doutora em Direito pela PUC/SP. Pós-Doutora pela UFSC.

Submissão em 12.11.2016

Aprovação em 19.11.2016

DOI: http://dx.doi.org/10.21671/rdufms.v2i1.2560

Resumo: $\mathrm{O}$ artigo visa analisar as causas relacionadas à proteção familiar e aos interesses da criança que impedem a expulsão de estrangeiro do Brasil. Para isto, expõem-se brevemente as questões que autorizam um Estado a retirar um indivíduo de seu território, bem como os mecanismos da deportação e da extradição. Discorre-se especificamente da expulsão e de suas características legais. Por fim, são examinadas as hipóteses que impedem a expulsão de estrangeiro que tenha criado vínculos familiares no país, sob a ótica da legislação nacional e das decisões das Cortes Superiores brasileiras em questões polêmicas e inovadoras. A pesquisa é bibliográfica e documental.

Palavras-chave: Soberania; Expulsão; Proteção da família; Interesses da criança; Direitos humanos.

Abstract: The article aims to analyze the causes related to family protection and the child's interests that prevent foreigners expulsion from Brazil. For this, the issues that allow a State to withdraw an 
individual from its territory, as well as the mechanisms of deportation and extradition are briefly exposed. Expulsion and its legal characteristics are specifically discussed. Finally, the hypotheses that prevent the expulsion of foreigners who have created family ties in the country are examined from the perspective of national legislation and from the decisions of Brazilian Superior Courts in polemic and innovative issues. The research is bibliographic and documental.

Keywords: Sovereignty; Expulsion; Family protection; Child's interests; Human rights.

SUMÁRIO: 1. Introdução. 2. Os mecanismos legais de retirada forçada do estrangeiro do território brasileiro. 2.1. Deportação. 2.2. Extradição. 3. 0 mecanismo da expulsão no Brasil. 4. a proteção da família como obstáculo à expulsão do estrangeiro. 4.1 A união de estrangeiro com cidadão brasileiro. 4.2. A existência de filho brasileiro. Conclusão. Referências.

\section{INTRODUÇÃo}

É costume de todo Estado possuir em sua legislação migratória normas que regulam o ingresso, a permanência e a retirada forçada de seu território de indivíduos não nacionais. No Brasil, a Lei n.o 6.815, de 19 de agosto de 1980, conhecida como Estatuto do Estrangeiro, juntamente com o seu regulamento, o Decreto n.. 86.715, de 10 de dezembro de 1981, são os responsáveis por disciplinar as questões migratórias brasileiras.

Nestes documentos legais se encontram os mecanismos de retirada forçada do estrangeiro do Brasil: a deportação, a extradição e a expulsão. Todos estes institutos se baseiam em questões relativas à soberania nacional

No entanto, com a solidificação dos preceitos dos direitos humanos a nível internacional por meio da Declaração Universal de 1948 e dos tratados internacionais pactuados entre as nações, as diretrizes voltadas à dignidade da pessoa passaram a fazer parte das ordens constitucionais da maioria dos Estados de Direito, influenciando na característica da soberania absoluta, de modo a relativizá-la em favor da proteção do indivíduo.

Nas questões migratórias não foi diferente, a proteção dos direitos humanos do indivíduo passou a ser considerada no momento do Estado decidir sobre sua permanência ou sua retirada de seu território.

Este artigo analisa os mecanismos de retirada forçada do estrangeiro do Brasil, em especial o instituto da expulsão, apresentando as características legais deste instrumento, com especial atenção quanto às causas impeditivas da discricionariedade do Estado brasileiro em expulsar o indivíduo de seu território. Tais causas se relacionam à proteção familiar e aos interesses da criança quando o estrangeiro cria vínculos familiares com algum cidadão brasileiro. 
Para esta análise, no primeiro item faz-se uma breve exposição sobre as questões que autorizam um Estado a retirar alguém do seu território, passando pela exposição sucinta dos mecanismos da deportação e da extradição. No segundo ponto do trabalho discorre-se especificamente acerca da expulsão de estrangeiro do Brasil, apresentando suas particularidades sob a ótica da legislação nacional e alguns documentos internacionais.

Por fim, são apresentadas as hipóteses que impedem a expulsão de estrangeiro que tenha criado vínculos familiares no país, ou seja, de indivíduo casado e/ou em união estável, ou que tenha filho brasileiro. Neste momento do trabalho, o exame destes impedimentos será feito com base na legislação migratória, levando-se em conta, principalmente, as decisões das Cortes Superiores brasileiras em questões polêmicas e inovadoras, como, por exemplo, a união homoafetiva e o momento de nascimento do filho, antes ou depois do fato que levou à abertura do processo expulsório.

A pesquisa é bibliográfica e documental, feita sob o método dedutivo, com fulcro nos ensinamentos de autores que tratam da temática migratória e do Direito Internacional, além de se utilizar da legislação nacional, de tratados internacionais e, principalmente, da jurisprudência dos Tribunais Superiores.

\section{Os MeCANiSmos Legais de ReTIRAda ForÇAda do Estrangeiro do TERRITÓRIO BRASILEIRO}

O fluxo migratório internacional é contínuo e a cada ano aumenta por diversos fatores ambientais, sociais, bélicos, etc. Os Estados devem estar preparados tanto do ponto de vista legal e jurídico, quanto do ponto de vista dos direitos humanos para receber os estrangeiros que adentram seu território. Sobre o disciplinamento do movimento migratório pelo Direito, no âmbito interno e internacional, escreve Cahali (1983, p.71):

O movimento migratório, próprio de todos os tempos com maior ou menor intensidade, representa um fenômeno irreversível das civilizações, restando ao direito apenas enquadrá-lo e equacionar-lhe as conseqüências.

O contínuo deslocamento de indivíduos, determinado por fatores sociais, religiosos, políticos e principalmente econômicos, reclama dos países que os acolhem uma disciplina jurídica adequada de composição dos limites: possibilidade de acesso do imigrante e preservação dos interesses nacionais.

A Declaração Universal dos Direitos Humanos, em seu artigo 13, item II, prescreve que "todo ser humano tem o direito de deixar qualquer país, inclusive o próprio, e a este regressar"; do mesmo modo, o item II, do artigo 22, da Con-

Revista DIREITO UFMS | Campo Grande, MS | v. 2 | n. 1 | p. 153 - 172 | jul./dez. 2016 
venção Americana sobre Direitos Humanos (Pacto de San José da Costa Rica) diz que "toda pessoa tem o direito de sair livremente de qualquer país, inclusive do próprio". Ambos os documentos consagram como direito humano a livre circulação de pessoas entre os países da comunidade internacional.

Entretanto, o Direito Internacional garante que nenhum Estado soberano é obrigado a permitir a entrada ou a permanência em seu território de pessoas que não possuam vínculos relacionados à nacionalidade, a qual, em regra, é regulamentada por normas constitucionais. Assim, por exclusão, “o estrangeiro é o não nacional" (CAHALI, 1983, p.11), ou seja, "aquele que não tem a nacionalidade do Estado em cujo território se encontra” (FRAGA, 1985, p.01).

De acordo as "Regras Internacionais sobre Admissão e Expulsão dos Estrangeiros”, estabelecidas na sessão de Genebra em 1892 do Instituto de Direito Internacional, "para cada Estado, o direito de admitir ou não estrangeiros em seu território, ou de admiti-lo apenas condicionalmente, ou de expulsá-los, é uma consequência lógica e necessária da sua soberania e de sua independência" (MAZZUOLI, 2008, p. 649).

0 artigo $1^{0}$ da Convenção Interamericana sobre Condição dos Estrangeiros enuncia que "os Estados tem o direito de estabelecer, por meio de leis, as condições de entrada e residência dos estrangeiros nos seus territórios". Esta convenção foi celebrada em Havana no ano de 1928 e ratificada pelo Brasil por meio do Decreto n.o 18.956 , de 22 de outubro de 1929.

Deste modo, a admissão de estrangeiros em seu território é ato discricionário do Estado, tendo como pressupostos a legislação interna, os tratados interestatais e o interesse público nacional. Porém, a negativa à concessão de permissão de ingresso do estrangeiro em seu território não poderá ser feita sob justificativas que possam configurar discriminação racial, ideológica, religiosa, de origem ou sexual.

No Brasil, compete exclusivamente à União legislar sobre emigração, imigração, entrada, extradição e expulsão de estrangeiros, conforme previsão do inciso XV, do artigo 22, da Constituição Federal. A condição jurídica do estrangeiro é disciplinada pela Lei n. ${ }^{\circ}$ 6.815, de 19 de agosto de 1980, conhecida como Estatuto do Estrangeiro, sendo regulamentada pelo Decreto n. $\stackrel{0}{86.715}$, de 10 de dezembro de 1981.

É no Estatuto do Estrangeiro que estão previstos os mecanismos legais de retirada forçada do estrangeiro do território nacional, sendo eles: a deportação, a expulsão, e a extradição. Os dois primeiros partem da iniciativa das autoridades estatais de onde o estrangeiro se encontra, já a extradição é requerida por outro Estado ao país onde o extraditando se encontra. 


\subsection{DEPORTAÇÃo}

A deportação consta nos artigos 57 a 64 da Lei n.. 6.815/1980, e nos artigos 98 e 99 do Decreto n. - 86.715/1981, sendo o instituto utilizado pelo Estado para retirar compulsoriamente o estrangeiro que entrar ou permanecer de forma irregular no país. Estas irregularidades dizem respeito à entrada clandestina; problemas nos documentos de identidade e/ou passaporte; expiração de visto; exercício de atividade remunerada pelos detentores de visto de turista, trânsito ou temporário; mudança de endereço não comunicada ao Ministério da Justiça, dentre outras enumeradas no $\S 11^{\circ}$, do artigo 57, da Lei de migrações.

Não se deve confundir a deportação com o impedimento à entrada, "no qual o estrangeiro não chega a efetivamente entrar no território nacional, não passando da barreira policial da fronteira, porto ou aeroporto, caso em queé mandado de volta" (MAZZUOLI, 2008, p. 654).

O estrangeiro deportado poderá ser enviado para o país de sua nacionalidade, país de procedência ou outro país no qual os requisitos de entrada permitam o seu ingresso. A deportação é ato individual, sendo vedada a deportação coletiva, bem como "se implicar em extradição inadmitida pela lei brasileira" (art. 63 do Estatuto).

A competência para realizar as deportações no Brasil é do Departamento de Polícia Federal, que notifica o estrangeiro e lhe concede o prazo de 03 (três) a 08 (oito) dias para a saída, dependendo da irregularidade que autoriza a retirada forçada. Caso o indivíduo não saia espontaneamente no prazo concedido, a deportação é feita imediatamente. A fixação de prazos não é obrigatória, podendo a deportação ser feita independentemente deste requisito, desde que seja conveniente aos interesses nacionais.

Caso fique comprovado que não houve responsabilidade da empresa transportadora pelas despesas com a retirada do estrangeiro, o Tesouro Nacional efetuará o pagamento das custas da deportação, se o estrangeiro ou terceiro não puder arcá-las.

0 estrangeiro poderá ser recolhido à prisão por ordem do Ministro da Justiça pelo prazo de 60 (sessenta) dias, enquanto a deportação não for efetivada. Este prazo poderá ser prorrogado por igual período, sempre que não for possível identificar o deportando ou obter documento de viagem para promover a sua retirada. Ao fim do prazo da prisão, o indivíduo é posto em liberdade vigiada.

A deportação poderá ser convertida em expulsão quando ela não for exequível ou quando houver sérios indícios de periculosidade ou indesejabilidade da permanência do estrangeiro em território nacional.

Por se tratar de medida administrativa e não punitiva, não se relacionando com a prática de crime, o estrangeiro poderá reingressar no território nacional 
quando sanadas as irregularidades que levaram a sua retirada, devendoressarcir o Tesouro Nacional pelas despesas com sua deportação, além de ser obrigado ao pagamento de multa que porventura tenha sido aplicada por conta das irregularidades cometidas. Brasileiros natos ou naturalizados não podem ser deportados.

\subsection{EXTRADIÇÃo}

O mecanismo da extradição é normatizado pelos artigos 76 a 94 do Estatuto do Estrangeiro e regulamentado pelo Decreto n.o 86.715/1981, no artigo 110 . Trata-se de ato bilateral de cooperação internacional no âmbito penal, no qual um Estado solicita a outro a entrega de indivíduo que violou suas leis penais ou que tenha sido condenado por descumpri-las, com o objetivo de levá-lo a julgamento ou ao cumprimento da pena imposta.

Caso não haja tratado bilateral de extradição entre o Brasil e o país requerente, é possível a extradição mediante a promessa de reciprocidade, ou seja, a promessa de análise de eventual pedido de extradição futuro. A extradição é diferente do instituto da entrega, sendo este aplicado em casos e situações diversas. A entrega é prevista no Estatuto de Roma do Tribunal Penal Internacional.

A extradição deverá ser requerida pela via diplomática ou, se houver previsão em tratado, ao Ministério da Justiça, não podendo ser baseada em atos ilícitos civis, administrativos ou fiscais, apenas na prática de crimes. Portanto, para ser extraditado, o indivíduo deve ter cometido ato que seja considerado crime tanto no Estado requerente como no Brasil (princípio da identidade, também conhecido como "dupla punibilidade" ou "dupla tipicidade"), este crime ainda não pode estar prescrito pela lei brasileira ou do país requerente, bem como não se admite a extradição por crimes de menor potencial ofensivo ou atos que "a lei brasileira impuser ao crime a pena de prisão igual ou inferior a 1 (um) ano" (inciso IV, art. 77 do Estatuto).

Se o estrangeiro estiver respondendo ou já respondeu por crime semelhante ao que se fundamenta o pedido de extradição, esta será indeferida por conta da proibição do bis in idem, não se admitindo novo pedido baseado no mesmo fato (art. 88 do Estatuto).

A extradição também não será concedia por crimes políticos ou de opinião, por força do inciso LII, do artigo 5o da Constituição Federal, uma vez que

[...] a vedação da extradição por crime político se deve, primeiramente, à subjetividade que normalmente envolve a criminalidade política, ou seja, ao fato de que o crime político amiúde é definido a partir de concepções ideológicas que não admitem a pluralidade de ideias. Com isso, o crime político choca-se diretamente com valores caros à demo-

Revista DIREITO UFMS | Campo Grande, MS | v. 2 | n. 1 | p. 153 - 172 | jul./dez. 2016 
cracia, atualmente mais valorizada nas relações internacionais, como a liberdade de expressão, de opinião, de reunião e de associação. Ainda nesse sentido, atos entendidos como "crimes políticos" em alguns Estados são vistos como normais e salutares em outros sistemas políticos, o que, aliás, descaracteriza o aspecto cooperativo da extradição. Outrossim, a definição do crime político costuma ser imprecisa, contrariando a necessidade de que os tipos penais sejam definidos com a maior clareza e precisão possíveis. Por fim, é comum que as sanções aos acusados de crimes políticos sejam totalmente contrárias à dignidade humana. (PORTELA, 2014, p. 343-344)

Do mesmo modo, a proibição constitucional de aplicação no Brasil das penas de morte e prisão perpétua (CF, art. 5o, XLVII, “a” e "b”), impede a extradição de estrangeiro que possa sofrer tais punições pelo Estado requerente. A possibilidade de o extraditando responder perante Tribunal de exceção também inadmite a sua extradição.

A extradição nunca atinge os brasileiros natos, apenas os estrangeiros e os brasileiros naturalizados. Estes últimos, em duas situações: quando o naturalizado cometeu crime comum antes da naturalização ou quando da pratica de crime de tráfico internacional de entorpecentes e drogas afins, nos termos da lei, conforme autoriza o inciso LI, do artigo 5ํㅜ, da Constituição brasileira.

A súmula n. 921 do Supremo Tribunal Federal (STF) autoriza a extradição de estrangeiro que é casado com brasileira ou tenha filho brasileiro ao expor que "não impede a extradição a circunstância de ser o extraditando casado com brasileira ou ter filho brasileiro".

A competência para processar e julgar os pedidos de extradição solicitados por Estado estrangeiro é do Supremo Tribunal Federal (alínea "g", inciso I, do art. 102, da Constituição), senda ratificada no artigo 83 do Estatuto do Estrangeiro. 0 Supremo apenas analisa os requisitos legais sobre o pedido de extradição, não sendo possível a análise do mérito do processo que o extraditando responde no exterior.

Entretanto, a palavra final da extradição será do Presidente de República, ou seja, o STF apenas analisa as formalidades legais do pedido do Estado requerente e, caso autorize a extradição, caberá ao Presidente concedê-la ou não, com base na sua discricionariedade, por conta do artigo 84, inciso VII, da Lei Maior. Se o STF não autorizar a extradição, o Presidente não poderá concedê-la.Este entendimento foi ratificado pelo julgamento da extradição n. ${ }^{0}$ 1.085, do italiano Cesare Battisti em 08 de junho de 2011, quando o STF autorizou a extradição e o então Presidente Luis Inácio Lula da Silva não a concedeu.

[...] 9. No campo da soberania, relativamente à extradição, é assente que o ato de entrega do extraditando é exclusivo, da competência indecliná-

Revista DIREITO UFMS | Campo Grande, MS | v. 2 | n. 1 | p. 153 - 172 | jul./dez. 2016 
vel do Presidente da República, conforme consagrado na Constituição, nas Leis, nos Tratados e na própria decisão do Egrégio Supremo Tribunal Federal na Extradição no 1.085. (...)12. 0 Presidente da República, no sistema vigente, resta vinculado à decisão do Supremo Tribunal Federal apenas quando reconhecida alguma irregularidade no processo extradicional, de modo a impedir a remessa do extraditando ao arrepio do ordenamento jurídico, nunca,contudo, para determinar semelhante remessa, porquanto, o Poder Judiciário deve ser o último guardião dos direitos fundamentais de um indivíduo, seja ele nacional ou estrangeiro, mas não dos interesses políticos de Estados alienígenas, os quais devem entabular entendimentos com o Chefe de Estado, vedada a pretensão de impor sua vontade através dos Tribunais internos. (...)(STF -Ext. n.ำ1.085. Relator: Min. Gilmar Mendes, Data de Julgamento:08/06/2011, Plenário)

Assim como a deportação, a extradição não possui caráter punitivo, pois é meio de "cooperação internacional para a repressão de crimes" (MAZZUOLI, 2008, p. 660), portanto, o estrangeiro extraditado poderá retornar ao Brasil após o cumprimento de sua pena com a justiça do Estado solicitante.

A expulsão é o mecanismo de retirada forçada do estrangeiro do território nacional que for considerado nocivo ou inconveniente aos interesses nacionais, $o$ qual será tratado com mais detalhes no item seguinte.

Vale ressaltar, por fim, que a partir do momento que o Estado brasileiro autoriza a permanência em caráter provisório ou permanente do estrangeiro em seu território, este indivíduo tem reconhecido os direitos e garantias fundamentais de qualquer cidadão, independentemente do motivo que o trouxe, por força do princípio da igualdade previsto no artigo $5^{0}$ da Cartaconstitucional.

\section{O MECANiSMo dA EXPUlSÃo No BRASIL}

A primeira vez que se mencionou legalmente sobre a expulsão de estrangeiro no Brasilfoi no Decreto n. ${ }^{\circ}$ 18.956, de 22 de outubro de 1929, o qual promulgou seis convenções de direito internacional publico, aprovadas pela Sexta Conferencia Internacional Americana, dentre as quais se encontrava a Convenção de Havana de 1928 sobre a Condição dos Estrangeiros, que estabelecia em seu artigo 60: "Os Estados podem, por motivo de ordem ou de segurança publica, expulsar o estrangeiro domiciliado, residente ou simplesmente de passagem pelo seu território".

A expulsão também está prevista em alguns documentos internacionais ratificados pelo Brasil. O Pacto Internacional sobre Direitos Civis e Políticos de 1966, objeto do Decreto n. 562, de 06 de julho de 1992, disciplina a expulsão em seu artigo 13:

Revista DIREITO UFMS | Campo Grande, MS | v. 2 | n. 1 | p. 153 - 172 | jul./dez. 2016 
Um estrangeiro que se ache legalmente no território de um Estado Parte do presente Pacto só poderá dele ser expulso em decorrência de decisão adotada em conformidade com a lei e, a menos que razões imperativas de segurança nacional a isso se oponham, terá a possibilidade de expor as razões que militem contra sua expulsão e de ter seu caso reexaminado pelas autoridades competentes, ou por uma ou varias pessoas especialmente designadas pelas referidas autoridades, e de fazer-se representar com esse objetivo.

A Convenção Americana sobre Direitos Humanos de 1969 (Pacto de São José da Costa Rica), incorporada ao ordenamento jurídico nacional pelo Decreto n.o 678, de 06 de novembro de 1992, traz no artigo 22 o direito de circulação e residência, onde se encontram os seguintes itens sobre a expulsão:

6. 0 estrangeiro que se ache legalmente no território de um Estado Parte nesta Convenção só poderá dele ser expulso em cumprimento de decisão adotada de acordo com a lei.

8. Em nenhum caso o estrangeiro pode ser expulso ou entregue a outro país, seja ou não de origem, onde seu direito à vida ou à liberdade pessoal esteja em risco de violação por causa da sua raça, nacionalidade, religião, condição social ou de suas opiniões políticas.

Já o artigo 3o da Convenção Contra a Tortura e Outros Tratamentos ou Penas Cruéis, Desumanos ou Degradantes de 1984, incorporada no Brasil pelo Decreto n. $\mathrm{o}$ 40, de 15 de fevereiro de 1991, preocupa-se com a possibilidade de tortura do estrangeiro expulso do território nacional:

1. Nenhum Estado Parte procederá à expulsão, devolução ou extradição de uma pessoa para outro Estado quando houver razões substanciais para crer que a mesma corre perigo de ali ser submetida a tortura.

2. A fim de determinar a existência de tais razões, as autoridades competentes levarão em conta todas as considerações pertinentes, inclusive, quando for o caso, a existência, no Estado em questão, de um quadro de violações sistemáticas, graves e maciças de direitos humanos.

Na legislação nacional, a expulsão estáprevista nos artigos 65 a 75 do Estatuto do Estrangeiro, e nos artigos 100 a 109 do Decreto n.o 86.715/1981. Este mecanismo de retirada forçada visa expulsar do país o estrangeiro que "de qualquer forma, atentar contra a segurança nacional, a ordem política ou social, a tranquilidade ou moralidade pública e a economia popular, ou cujo procedimento o torne nocivo à conveniência e aos interesses nacionais" (art. 65 do Estatuto).

Além disso, é passível de expulsão, segundo o parágrafo único, do artigo 65, o estrangeiro que "praticar fraude a fim de obter a sua entrada ou permanência 
no Brasil; havendo entrado no território nacional com infração à lei, dele não se retirar no prazo que lhe for determinado para fazê-lo, não sendo aconselhável a deportação; entregar-se à vadiagem ou à mendicância; ou desrespeitar proibição especialmente prevista em lei para estrangeiro".

Como se depreende, o instituto da expulsão é ato discricionário de soberania nacional. Os motivos que o autorizam se revestem de subjetividade, cabendo à autoridade competente decidir sobre a sua autorização, no entanto, esta discricionariedade não é absoluta, devendo ser pautada nos limites legais e nos princípios constitucionais.

No Brasil, o Presidente da República é a autoridade competente para resolver sobre a conveniência e a oportunidade da expulsão ou de sua revogação, o fazendo por meio de Decreto publicado no Diário Oficial da União. Entretanto, desde o ano 2000, o Presidente delegou esta competência ao Ministro da Justiça (Decreto n. 3.447 , de 05 de maio de 2000), que deverá decidir sobre a expulsão por publicação de Portaria. Da decisão da expulsão cabe pedido de reconsideração no prazo de 10 (dez) dias contados da publicação no Diário Oficial.

Para haver a expulsão é necessária a instauração de processo administrativo (inquérito) junto ao Ministério da Justiça, cabendo ao Ministro determiná-la de ofício ou mediante solicitação fundamentada. Ainda segundo o Estatuto do Estrangeiro, o Ministério Público remeterá de ofício ao Ministério da Justiça, em até trinta dias após o trânsito em julgado, “cópia da sentença condenatória de estrangeiro autor de crime doloso ou de qualquer crime contra a segurança nacional, a ordem política ou social, a economia popular, a moralidade ou a saúde pública, assim como da folha de antecedentes penais constantes dos autos" (art. 68).

Recebidos os documentos do Ministério Público, o parágrafo único do artigo 68 não prescreve a discricionariedade, o Ministro da Justiça determinará a instauração do inquérito para a expulsão do estrangeiro.

É autorizada, ao Ministro da Justiça, a decretação da prisão por até 90 (noventa) dias, do estrangeiro que estiver sendo submetido a processo de expulsão, podendo prorrogá-la por igual período quando necessitar para fins de conclusão do inquérito ou para assegurar a execução da medida. Se o Judiciário suspender provisoriamente a efetivação do ato expulsório, o prazo de prorrogação da prisão ficará interrompido até a decisão definitiva do Tribunal.

Quando não for necessária a prisão ou quando o prazo desta tenha vencido, o estrangeiro ficará em liberdade vigiada em lugar designado pelo Ministro da Justiça, devendo obedecer a normas de comportamento a ele estabelecidas. As normas de conduta e o local de residência do estrangeiro podem ser modificadas pelo Ministro de ofício ou a pedido. 
Há a possibilidade de instauração de inquérito sumário de expulsão, o qual não excederá o prazo de 15 (quinze) dias, nos casos em que o estrangeiro cometer infrações "contra a segurança nacional, a ordem política ou social e a economia popular, assim como nos casos de comércio, posse ou facilitação de uso indevido de substância entorpecente ou que determine dependência física ou psíquica, ou de desrespeito à proibição especialmente prevista em lei para estrangeiro" (art. 71 do Estatuto). Tanto no inquérito sumário, como no inquérito regular, o direito à ampla defesa e ao contraditório devem ser garantidos ao estrangeiro (art. 5, LV, Constituição Federal).

Relevante mencionar que há críticas quanto à possibilidade de decretação de prisão do estrangeiro pelo Ministro da Justiça tanto no caso da expulsão, quanto na deportação, uma vez que este ato afrontaria a competência constitucional do Poder Judiciário, prevista no artigo 5ํㅜ , inciso LXI da Magna Carta. Os críticos escrevem que os artigos 61, 73 e 139 da Lei n. 6.815/1980, não foram recepcionados pela Constituição de 1988.

O estrangeiro que for expulso não poderá retornar ao território brasileiro, salvo quando houver revogação do ato de expulsão (decreto ou portaria) emitido pela mesma autoridade que o expulsou. Ao ser expulso, o estrangeiro poderá ir para qualquer país que aceite recebê-lo.

Caso retorne indevidamente ao Brasil, o indivíduo estará cometendo o crime de reingresso de estrangeiro expulso, tipificado no artigo 338, do Código Penal, podendo ser condenado de 01 (um) a 04 (quatro) anos de reclusão, sem prejuízo de nova expulsão após o cumprimento da pena. Para esta nova expulsão mencionada na Lei penal, não necessita ser aberto novo inquérito administrativo junto ao Ministério da Justiça.

Este mecanismo de retirada forçada de estrangeiro não pode ser considerado uma pena no âmbito criminal, mas sim uma medida político-administrativa inerente ao poder de polícia do Estado. Mazzuoli (2008, p. 656) assim explica:

A expulsão não é pena no sentido criminal, uma vez que o legislador brasileiro não a incluiu no elenco dessas medidas jurídico-penais. É, sim, medida político-administrativa (que não deixa, por isso, de ser repressi$v a$ ) inerente ao poder de polícia do Estado, sem qualquer intervenção do Poder Judiciário no que tange ao mérito da decisão. Trata-se de medida administrativa discricionáriae não de ato arbitrário do governo, como se poderia pensar à primeira vista. A diferença é que, neste último caso, não existem condições nem limites à atuação do Executivo, enquanto naquela (na medida discricionária) o governo está condicionado às hipóteses previstas em lei, sendo o seu ato irrestrito tão-somente no que tange à conveniência e oportunidade da medida. A discricionariedade é permissiva da medida, não estando o governo obrigado a procedê-la, 
mesmo nos casos em que todos os requisitos necessários à sua realização se façam presentes (Grifos do autor).

Apesar de não poder adentrar no mérito da questão, por ser ato privativo do Poder Executivo, o Judiciário poderá intervir quando acionado pelo estrangeiro que se sentir de alguma forma prejudicado durante o inquérito de expulsão, já que continua a lhe ser garantido o direito de petição, com base no princípio constitucional da inafastabilidade do controle jurisdicional, consagrado no artigo 5ㅜㅜ inciso XXXV, da Constituição Federal. Comumente o estrangeiro submetido ao mecanismo da expulsão ingressa com habeas corpus no Superior Tribunal de Justiça, quando o ato é portaria ministerial ouno Supremo Tribunal Federal, quando o ato é decreto presidencial, conforme leciona Yussef Said Cahali (1983, p.252):

[...] o poder discricionário que o art. 66 do Estatuto concede ao mais alto mandatário do País não descarta sumariamente do controle jurisdicional o decreto expulsório; sendo o habeas corpus a via de impugnação mais adequada, com a competência privativa do Supremo Tribunal Federal para sua apreciação.

A expulsão só será feita contra estrangeiros. Brasileiros natos ou naturalizados não podem ser expulsos do país, uma vez que a Constituição veda a pena de banimento (art. 5ํ, XLVII, "d"). Do mesmo modo, é proibida a expulsão de estrangeiro que objetivar pedido de refúgio, por conta do princípio do non refoulement, bem como a expulsão coletiva de estrangeiros, devido à vedação escrita no item 9, do artigo 22, da Convenção Americana sobre Direitos Humanos.

0 artigo 75 do Estatuto do Estrangeiro elenca três impedimentos à expulsão de estrangeiro do Brasil. In verbis:

Art. 75. Não se procederá à expulsão:

I - se implicar extradição inadmitida pela lei brasileira; ou

II - quando o estrangeiro tiver:

a) Cônjuge brasileiro do qual não esteja divorciado ou separado, de fato ou de direito, e desde que o casamento tenha sido celebrado há mais de 5 (cinco) anos; ou

b) filho brasileiro que, comprovadamente, esteja sob sua guarda e dele dependa economicamente.

Como se observa, estas causas impeditivas limitam a discricionariedade do Estado ao analisar o processo de expulsão de estrangeiro, devendo o indivíduo suscitá-las no decorrer de seu inquérito. Os dois impedimentos expostos no inciso II dizem respeito à proteção familiar, estando sob a seara do Direito de Família, os quais serão analisados mais detalhadamente no próximo tópico deste trabalho. 


\section{A Proteção da Família como Obstáculo À Expulsão do ESTRANGEIRO}

Conforme já adiantado, as duas hipóteses que impedem a expulsão do estrangeiro do território brasileiro se relacionam diretamente à proteção da família e do Direito de Família, em consonância ao prescrito no item 3, do artigo XVI da Declaração Universal dos Direitos Humanos: "A família é o núcleo natural e fundamental da sociedade e tem direito à proteção da sociedade e do Estado".

A análise destas causas impeditivas será feita com base na legislação e jurisprudências recentes que orientam como o Estado brasileiro deve proceder quando o estrangeiro possuir vínculos familiares no País.

\subsection{A União de EstrangeIro com Cidadão Brasileiro}

Apesar do Estatuto do Estrangeiro mencionar na alínea "a", do inciso II, do art. 75, o impedimento à expulsão de estrangeiro que não estiver separado ou divorciado de cônjuge brasileiro, e que o casamento tenha sido celebrado há mais de 05 (cinco) anos, é necessário estender a previsão desta causa impeditiva à união estável, devidamente reconhecida como entidade familiar pela legislação civil e constitucional brasileira, devendo ser protegida pelo Estado $(\S 3 \stackrel{0}{\text {, }}$, do art. 226, da Constituição).

Maria Berenice Dias escreve sobre a simetria entre casamento e união estável:

Ninguém duvida que há quase uma simetria entre casamento e união estável. Ambas são estruturas de convívio que têm origem em elo afetivo. A divergência diz só com o modo de constituição. Enquanto o casamento tem seu início marcado pela celebração do matrimônio, a união estável não tem termo inicial estabelecido. Nasce da consolidação do vínculo de convivência, do comprometimento mútuo, do entrelaçamento de vias e do embaralhar de patrimônios. (DIAS, 2011, p.171) (Grifos da autora)

Há jurisprudência dos Tribunais Superiores que demonstram que a união estável também impede a expulsão de estrangeiro, desde que observado prazo de mais de 05 (cinco) anos de convivência. Veja decisão do Supremo Tribunal Federal (STF) do ano 2000 que já ratificava o posicionamento:

DIREITO INTERNACIONAL, CONSTITUCIONAL E ADMINISTRATIVO. EXPULSÃO DE ESTRANGEIRO QUE, NO BRASIL, CUMPRIU PENA POR CRIME DE TRÁFICO DE ENTORPECENTES, AQUI PRATICADO. "HABEAS CORPUS". Alegação de constrangimento ilegal, decorrente do ato expulsório, por inobservância do disposto no art. 75, II, a, da Lei no 6.815/80, alterada pela Lei no $6.964 / 81$, já que o expulsando teria mantido união

Revista DIREITO UFMS | Campo Grande, MS | v. 2 | n. 1 | p. 153 - 172 | jul./dez. 2016 
estável com brasileira, no país (art. 226, parágrafo 3o, da Constituição Federal). Inocorrência dessa hipótese. 0 fato de o expulsando ter sido visitado pela amásia, na prisão, durante certo período, enquanto esteve cumprindo pena, não configura a hipótese prevista no art. 75, II, a, da Lei no 6.815/80, alterada pela Lei no 6.964/81, nem a união estável de que trata o parágrafo $3^{\circ}$ do art. 226 da C.F., de modo a obstar, no caso, a expulsão. "H.C." indeferido. (STF - HC: 80322 SP, Relator: Min. Sydney Sanches, Data de Julgamento: 18/10/2000, Tribunal Pleno).

No entanto, desde 05 de maio de 2011, ao julgar a Ação Direta de Inconstitucionalidade n. 4277 e a Arguição de Descumprimento de Preceito Fundamental n. - 132, o STF admite o reconhecimento da união homoafetiva, com base nos preceitos fundamentais da igualdade, liberdade e dignidade da pessoa humana, estendendo aos companheiros nas uniões entre pessoas do mesmo sexo, os mesmos direitos e deveres das uniões estáveis heterossexuais. Assim decidiram os ministros sobre a união homoafetiva:

4. UNIÃO ESTÁVEL. NORMAÇÃO CONSTITUCIONAL REFERIDA A HOMEM E MULHER, MAS APENAS PARA ESPECIAL PROTEÇÃO DESTA ÚLTIMA. FOCADO PROPÓSITO CONSTITUCIONAL DE ESTABELECER RELAÇÕES JURÍDICAS HORIZONTAIS OU SEM HIERARQUIA ENTRE AS DUAS TIPOLOGIAS DO GÊNERO HUMANO. IDENTIDADE CONSTITUCIONAL DOS CONCEITOS DE “ENTIDADE FAMILIAR” E “FAMÍLIA”. (...) A Constituição não interdita a formação de família por pessoas do mesmo sexo. Consagração do juízo de que não se proíbe nada a ninguém senão em face de um direito ou de proteção de um legítimo interesse de outrem, ou de toda a sociedade, o que não se dá na hipótese sub judice. Inexistência do direito dos indivíduos heteroafetivos à sua não-equiparação jurídica com os indivíduos homoafetivos. Aplicabilidade do $§ 2^{\circ}$ do art. 5o da Constituição Federal, a evidenciar que outros direitos e garantias, não expressamente listados na Constituição, emergem "do regime e dos princípios por ela adotados", verbis: "Os direitos e garantias expressos nesta Constituição não excluem outros decorrentes do regime e dos princípios por ela adotados, ou dos tratados internacionais em que a República Federativa do Brasil seja parte" (STF - ADI: 4277-DF, Relator: Min. Ayres Britto, Data de Julgamento: 05/05/2011, Plenário)

A partir desta decisão paradigmática, fica evidente o impedimento da expulsão de estrangeiro que faça parte de união homoafetiva devidamente comprovada no prazo mínimo estabelecido no artigo 75 do Estatuto do Estrangeiro. Transcreve-se decisão do Superior Tribunal de Justiça (STJ) a respeito do tema:

ADMINISTRATIVO. HABEAS CORPUS. TRÁFICO ILÍCITO DE ENTORPECENTES. EXPULSÃO DE ESTRANGEIRA DO TERRITÓRIO NACIONAL. 
AUSÊNCIA DE DEFESATÉCNICA. NULIDADE. NÃO CONFIGURAÇÃO. SÚMULA VINCULANTE 5/STF.CONVIVÊNCIA SOCIOAFETIVA, DEPENDÊNCIA ECONÔMICA E EMPREGO FIXODEMONSTRADOS. PRECEITOS FUNDAMENTAIS. CIDADANIA E DIGNIDADE DAPESSOA HUMANA. CONSTRANGIMENTO ILEGAL EVIDENCIADO. ORDEM CONCEDIDA. (...) 7. Não se mostra razoável a expulsão de estrangeira que se encontracom sua vida solidificada em nosso país, tendo cumprido a pena quelhe foi imposta pelo Estado brasileiro, e não havendo, desde suasoltura em 2004 até a presente data, nenhum registro de ocorrênciaque desabone sua conduta social. Ao contrário, parece ter constituído família (união homoafetiva) e mantém relação de trabalhocom empresa brasileira. 8 . Ordem concedida. (ST) - HC: 198169 SP 2011/0036779-1, Relator: Ministro Arnaldo Esteves Lima, Data de Julgamento: 14/09/2011, S1 - Primeira Seção, Data de Publicação: DJe 16/11/2011) (Grifo nosso)

Assim, aduz Maria Berenice Dias a respeito do reconhecimento da união homoafetiva pelo Judiciário:

É no âmbito do Judiciário que, batizadas com o nome de uniões homoafetivas, as uniões de pessoas do mesmo sexo começaram a encontrar reconhecimento. Com isso as barreiras do preconceito vêm, aos poucos, arrefecendo e cedendo lugar a que os vínculos afetivos sejam compreendidos sem que se interrogue a identidade dos parceiros. Vencer o preconceito é uma luta árdua, que vem sendo travada diuturnamente, e que, aos poucos, de batalha em batalha, tem se mostrado exitosa numa guerra desumana. (DIAS, 2011, p. 197)

A afetividade está presente nas uniões estáveis e uniões homoafetivas, sendo uma característica inerente desta entidade família. A seguir, será demonstrado que a afetividade também é levada em conta pelas Cortes ao decidirem sobre a expulsão de estrangeiros que possuem filhos brasileiros.

\subsection{A EXISTÊNCIA DE FILHo BRASILEIRo}

O Estatuto do Estrangeiro é claro quando impede a expulsão de estrangeiro que possua filho brasileiro, o qual esteja sob sua guarda e dependência econômica, de modo comprovado. Ressalva-seo não impedimento da expulsãoquando houver a adoção ou o reconhecimento de filho brasileiro após o fato motivador (art. 75, § 1ํ).

A proibição neste caso visa garantir os interesses da criança, tendo por fundamento o direito ao convívio familiar. Assim asseverou o STJ:

HABEAS CORPUS. LEI 6.815/80 (ESTATUTO DO ESTRANGEIRO). EXPULSÃO. ESTRANGEIRO COM PROLE NO BRASIL. FATOR IMPEDITIVO. TUTELA DOINTERESSE DAS CRIANÇAS. ARTS. 227 E 229 DA CF/88. DECRETO

Revista DIREITO UFMS | Campo Grande, MS | v. 2 | n. 1 | p. 153 - 172 | jul./dez. 2016 
99.710/90- CONVENÇÃO SOBRE OS DIREITOS DA CRIANÇA. 1. A regra do art. 75, II, b, da Lei 6.815/80 deve ser interpretadasistematicamente, levando em consideração, especialmente, osprincípios da CF/88, da Lei 8.069/90 (ECA) e das convençõesinternacionais recepcionadas por nosso ordenamento jurídico. 2. A proibição de expulsão de estrangeiro que tenha filho brasileiro objetiva resguardar os interesses da criança, não apenas no que serefere à assistência material, mas à sua proteção em sentidointegral, inclusive com a garantia dos direitos à identidade, àconvivência familiar, à assistência pelos pais. 3. Ordem concedida. (STJ - HC: 31449 DF 2003/0196013-6, Relator: Ministro Francisco Falcão, Data de Julgamento: 12/05/2004, S1 - Primeira Seção, Data de Publicação: DJ 31/05/2004)

A primeira controvérsia sobre a alínea "b", do inciso II, do art. 75, da Lei n. o 6.815/1980 é quanto à cumulatividade ou não da guarda e da dependência econômica, uma vez que a lei escreve "esteja sob sua guarda e dele dependa economicamente" (grifo nosso). A princípio, a cumulatividade é necessária, devido à orientação do STF:

1. EXPULSÃO. Estrangeiro condenado por tráfico de entorpecentes. Filha brasileira. Reconhecimento ulterior à expedição do Decreto de expulsão. Inexistência, ademais, dos requisitos simultâneos da guarda e da dependência econômica. Não ocorrência de causa impeditiva. HC denegado. Interpretação do art. 75, caput, inc. II, letra b, e $§ 1$ ํㅡㄹ da Lei n.. 6.815/90 (sic). A existência de filha brasileira só constitui causa impeditiva da expulsão de estrangeiro, quando sempre a teve sob sua guarda e dependência econômica, mas desde que a tenha reconhecido antes do fato que haja motivado a expedição do decreto expulsório. (...) (STJ - HC: 82893-SP, Relator Min. Cezar Peluso. Julgamento: 17/12/2004. Tribunal Pleno)

Fica a dúvida quando a guarda é de um dos pais ou quando há guarda compartilhada, recentemente normatizada. Contudo, nos últimos anos os julgadores estão se baseando em requisito mais abrangente que a guarda e dissociável da dependência econômica: o afeto entre o estrangeiro e seu filho.

Para Flávio Tartuce (2007, p. 12), “o afeto talvez seja apontado, atualmente, como o principal fundamento das relações familiares. Mesmo não constando a palavra afeto no Texto Maior como um direito fundamental, podemos dizer que o afeto decorre da valorização constante da dignidade humana".

Neste sentido, o próprio Supremo já reconhece que a existência da afetividade e da "dependência socioafetiva" (PORTELA, 2014, p. 333), devidamente comprovada, entre estrangeiro e seu filho brasileiro, pode ensejar a obstrução da discricionariedade do Estado em expulsá-lo de seu território ${ }^{52}$. Observe:

${ }^{52}$ Vale constar que a afetividade é prevista no $\$ 3^{\circ}$, do art. 28 do Estatuto da Criança e do Adolescente (Lei $8.69 / 90)$ e no artigo $1.584, \S 5^{\circ}$ do Código Civil.

Revista DIREITO UFMS | Campo Grande, MS | v. 2 | n. 1 | p. 153 - 172 | jul./dez. 2016 
Habeas corpus. Medida liminar. Expulsão de estrangeiro. Paternidade sobre filho menor impúbere brasileiro nascido após a prática do delito ensejador do ato de expulsão. 0 status quaestionis na jurisprudência do Supremo Tribunal Federal. Condições de inexpulsabilidade: dependência econômica ou vínculo sócio-afetivo. Considerações em torno do afeto como valor constitucional irradiador de efeitos jurídicos. A valorização desse novo paradigma como núcleo conformador do conceito de família. A relação sócio-afetiva como causa obstativa do poder expulsório do estado. Dever constitucional do estado de proteger a unidade e de preservar a integridade das entidades familiares fundadas em relações hétero ou homoafetivas. Necessidade de proteção integral e efetiva à criança e/ou ao adolescente nascidos no brasil. Plausibilidade jurídica da pretensão cautelar. Configuração do "periculum in mora". Medida cautelar deferida.(STF - HC: 114901 CE, Relator: Min. Celso de Mello, Data de Julgamento: 26/11/2012)

Como se interpreta, a aplicação do Estatuto do Estrangeiro está deixando de ser feita somente pela ótica da literalidade da lei, sendo também considerados os preceitos constitucionais, de direitos humanos e, principalmente, da Convenção sobre os Direitos da Criança, a qual foi incorporada no ordenamento jurídico nacional pelo Decreto n.o 99.710, de 21 de novembro de 1990. Consequentemente, o vínculo afetivo não deve ser restrito apenas ao parentesco biológico, como também ao parentesco entre pai/mãe e filho adotivo.

Importante destacar outra grande controvérsia nesta questão envolvendo estrangeiro e filho brasileiro: a cronologia da "existência" do filho brasileiro. A jurisprudência encontra-se dividida na autorização da expulsão de estrangeiro quando o nascimento de seu filho brasileiro ocorrer após o fato motivador.

A divergência possui tamanha importância que em 2011 foi elevada ao Supremo Tribunal Federal sob o status de Repercussão Geral, ainda aguardando julgamento pelo Plenário da Corte.

ESTRANGEIRO - EXPULSÃO - FILHO BRASILEIRO - SOBERANIA NACIONAL VERSUS FAMÍLIA - REPERCUSSÃO GERAL CONFIGURADA. Possui repercussão geral a controvérsia acerca da possibilidade de expulsão de estrangeiro cujo filho brasileiro nasceu posteriormente ao fato motivador do ato expulsório. (STF - RE 608898 RG-SP, Relator: Min. Marco Aurélio. Julgamento: 10/03/2011).

Desta feita, o STF terá que decidir sobre a ordem cronológica de nascimento do filho brasileiro de estrangeiro que enfrenta processo de expulsão, como fato que impedirá ou não a sua expulsão. Ou seja, como coloca o Ministro Marco Aurélio em seu voto de reconhecimento da repercussão geral, se está "diante de conflito de interesse do Estado brasileiro, no tocante à pro-

Revista DIREITO UFMS | Campo Grande, MS | v. 2 | n. 1 | p. 153 - 172 | jul./dez. 2016 
teção de direitos e garantias fundamentais aparentemente conflitantes, com reflexos interna e internacionalmente".

Não se pode olvidar que se verificado o abandono do filho, o divórcio ou a separação, de fato ou de direito, a qualquer tempo poderá ser efetivada a expulsão. É o que determina o $§ 2^{\circ}$, do artigo 75, do Estatuto do Estrangeiro.

Por fim, imperativo expor a necessidade de revisão da redação da Súmula n. 1 do STF, a qual prescreve que "é vedada a expulsão de estrangeiro casado com brasileira, ou que tenha filho brasileiro, dependente da economia paterna". Primeiramente, diferente da Lei n. ㅇ 6.815/80 que consta "cônjuge brasileiro", a súmula especifica que o casamento tenha sido contraído com brasileira. Ademais, a dependência econômica "paterna", deve ser entendida em sentido amplo, pois haverá casos de dependência econômica materna. Ainda, especifica a questão do casamento, não constando a união estável. A igualdade entre homens e mulheres e a união estável devem ser levadas em conta no momento da interpretação deste entendimento sumulado da Suprema Corte.

\section{ConCLUSÃo}

O caráter absoluto da soberania nacional vem sendo relativizado ao longo dos anos. Os sistemas internacionais e regionais de proteção dos direitos humanos é um dos motivos que levaram a esta relativização, uma vez que a dignidade da pessoa humana deve ser respeitada em qualquer país da comunidade internacional, com base na universalidade destes direitos, já proclamada tanto na Declaração Universal de 1948, quanto na Convenção de Viena de 1993.

Desta feita, apesar de serem previstos no ordenamento jurídico brasileiro, os mecanismos de retirada forçada de estrangeiro do território nacional não devem afrontar os preceitos básicos dos direitos humanos, tampouco os princípios constitucionais inerentes ao Estado de Direito. A importância da proteção da família e dos interesses das crianças deve ser considerada sob o status de igualdade com a soberania nacional, devendo cada caso ser analisado com zelo por parte das autoridades estatais e judiciais.

A expulsão é medida extrema, que impede o retorno do estrangeiro ao Brasil, ou seja, há o rompimento familiar e afetivo entre o indivíduo e sua família composta por cidadãos nacionais por conta de ordem discricionária estatal. Até que seja feita uma revisão e atualização legislativa, cabe ao Poder Judiciário, por meio de suas decisões, adequar as leis migratórias à nova realidade de respeito às diferenças, de proteção e promoção dos direitos humanos e de observância dos princípios da Constituição Federal e dos tratados internacionais ratificados pelo Estado brasileiro. 
A união estável, a união homoafetiva, o direito ao convívio familiar entre cônjuges/companheiros e os filhos, a afetividade, bem como os interesses da criança, devem ser levados em conta nos processos de expulsão de estrangeiro que tenha criados vínculos familiares no Brasil. Espera-se que o Supremo Tribunal Federal considere a cronologia do nascimento do filho brasileiro após o fato motivador da expulsão, como uma causa não absoluta de autorização da retirada forçada do estrangeiro do território brasileiro.

\section{REFERÊNCIAS}

BRASIL. Câmara dos Deputados. Decreto n.o 18.956, de 22 de outubro de 1929. Promulga seis convenções de direito internacional publico, aprovadas pela Sexta Conferencia internacional americana. Diário Oficial da República Federativa do Brasil, Rio de Janeiro, 12 dez. 1929. Disponível em: <http://www2.camara.leg.br/legin/fed/ decret/1920-1929/decreto-18956-22-outubro-1929-549004-publicacaooriginal-64267-pe.html>. Acesso em: 26 mai. 2016.

Constituição da República Federativa do Brasil de 1988. Promulgada em 5 de outubro de 1988. Diário Oficial da República Federativa do Brasil, Brasília, DF, 05 out. 1988. Disponível em: <http://www.planalto.gov.br/ccivil_03/constituicao/constituicaocompilado.htm>. Acesso em 25 mai. 2016.

. Decreto n.o 40, de 15 de fevereiro de 1991. Promulga a Convenção Contra a Tortura e Outros Tratamentos ou Penas Cruéis, Desumanos ou Degradantes. Diário Oficial da República Federativa do Brasil. Brasília, DF, 18 de fevereiro de 1991. Disponível em: < <ttp:// www.planalto.gov.br/ccivil_03/decreto/1990-1994/D0040.htm>. Acesso em 29 mai. 2016.

. Decreto n.o 562, de 06 de julho de 1992. Atos Internacionais. Pacto Internacional sobre Direitos Civis e Políticos. Promulgação. Diário Oficial da República Federativa do Brasil. Brasília, DF, 07 de julho de 1992. Disponível em: <http://www.planalto.gov.br/ccivil_03/ decreto/1990-1994/d0592.htm>. Acesso em 29 mai. 2016.

. Decreto n.․․ 678, de 06 de novembro de 1992. Promulga a Convenção Americana sobre Direitos Humanos (Pacto de São José da Costa Rica), de 22 de novembro de 1969. Diário Oficial da República Federativa do Brasil. Brasília, DF, 09 de novembro de 1992. Disponível em:<http://www.planalto.gov.br/ccivil_03/decreto/D0678.htm>. Acesso em 29 mai. 2016.

Lei no 6.815, de 19 de agosto de 1980. Define a situação jurídica do estrangeiro no Brasil, cria o Conselho Nacional de Imigração. Diário Oficial da República Federativa do Brasil, Brasília, DF, 21 ago. 1980. Disponível em: <http://www.planalto.gov.br/CCIVIL_03/leis/L6815compilado.htm>. Acesso em: 19 jul. 2015.

Superior Tribunal de Justiça. Habeas Corpus n.o 198.169-SP. Paciente: Cláudia Marisa Aguia Lopes. Impetrante: Bruno Pereira Gomes. Impetrado: Ministro de Estado de Justiça. Relator: Ministro Aroldo Esteves Lima. Brasília, 14 de setembro de 2011. Disponível em: <http://stj.jusbrasil.com.br/jurisprudencia/21047180/habeas-corpus-hc-198169-sp-2011-0036779-1-stj>. Acesso em 30 mai. 2016.

Superior Tribunal de Justiça. Habeas Corpus n. ${ }^{\circ}$ 31.449-DF. Paciente: Emmanuel Abioudun Dipeolu. Impetrante: Fabiana Mendes dos Santos. Impetrado: Ministro de Estado da Justiça. Relator: Francisco Falcão. Brasília, 12 de maio de 2004. Disponível em: <ht-

Revista DIREITO UFMS | Campo Grande, MS | v. 2 | n. 1 | p. 153 - 172 | jul./dez. 2016 
tps://ww2.stj.jus.br/processo/pesquisa/?src=1.1.3\&aplicacao=processos.ea\&tipoPesquisa=tipoPesquisaGenerica\&num_registro=200301960136> . Acesso em 30 mai. 2016.

Superior Tribunal de Justiça. Habeas Corpus n.ำ 82.893-SP. Paciente: John Nwolisa. Impetrante: Dolores Rodrigues Pinto. Impetrado: Ministro da Justiça. Relator: Min. Cezar Peluso. Brasília, 17 de dezembro de 2004. Disponível em:<http://stf.jusbrasil.com.br/ jurisprudencia/766195/habeas-corpus-hc-82893-sp>. Acesso em 30 mai. 2016.

Supremo Tribunal Federal. Ação Direta de Inconstitucionalidade n.o 4.277-DF. Requerente: Procuradoria-Geral da República. Relator: Ministro Ayres Britto. Brasília, 05 de maio de 2011. Disponível em: <http://redir.stf.jus.br/paginadorpub/paginador.jsp?doc$\mathrm{TP}=\mathrm{AC} \&$ docID=628635> . Acesso em 30 mai. 2016.

. Supremo Tribunal Federal. Habeas Corpus n. 0.322-SP. Paciente: José Horácio Hernandes Rueda ou Ramon Compte Badia. Coator: Presidente da República. Relator: Ministro Sydney Sanches. Brasília, 18 de outubro de 2000. Disponível em: <http://stf.jusbrasil.com. br/jurisprudencia/14752806/habeas-corpus-hc-80322-sp>. Acesso em 30 mai. 2016.

. Supremo Tribunal Federal. Informativo n. ${ }^{\circ}$ 690. Brasília, DF, 26 a 30 de novembro de 2012. Processo Habeas Corpus n.o 114.901-DF. Disponível em: <http://www.stf.jus.br/arquivo/informativo/documento/informativo690.htm\#transcricao>. Acesso em 30 mai. 2016.

Supremo Tribunal Federal. Petição Avulsa na Extradição 1.085 República Italiana. Requerente: Governo da Itália. Extraditando: Cesare Battisti. Relator: Ministro Gilmar Mendes. Brasília, 08 de junho de 2011. Disponível em: <http://redir.stf.jus.br/paginadorpub/paginador.jsp?docTP=AC\&docID=630001>. Acesso em 28 mai. 2016.

Supremo Tribunal Federal. Repercussão Geral no Recurso Extraordinário n. 608.898 -SP. Requerente: União. Requerido: Edd Abadallah Mohamed. Relator: Ministro Marco Aurélio. Brasília, 10 de março de 2011. Disponível em: <http://redir.stf.jus.br/paginadorpub/paginador.jsp?docTP=AC\&docID=628058>. Acesso em 30 mai. 2016.

. Supremo Tribunal Federal. Súmula $n^{\circ} 421$. Não impede a extradição a circunstância de ser o extraditando casado com brasileira ou ter filho brasileiro. Disponível em: $<$ http://www.stf.jus.br/portal/cms/verTexto.asp?servico=jurisprudenciaSumula\&pagina=sumula_401_500>. Acesso em 28 mai. 2016.

CAHALI, Yussef Said. Estatuto do Estrangeiro. São Paulo: Saraiva, 1983.

DIAS, Maria Berenice. Manual de Direito das Famílias. 8 ed. rev. e atual. São Paulo: Revista dos Tribunais, 2011.

FRAGA, Mirtô. O Novo Estatuto do Estrangeiro Comentado. Rio de Janeiro: Forense, 1985.

MAZZUOLI, Valerio de Oliveira. Curso de Direito Internacional Público. 3. ed. rev., atual. e ampl. São Paulo: Revista dos Tribunais, 2008.

ORGANIZAÇÃO DAS NAÇÕES UNIDAS. Declaração Universal dos Direitos Humanos. 1948. Disponível em: <http://www.dudh.org.br/wp-content/uploads/2014/12/dudh.pdf>. Acesso em 13 jul. 2015.

PORTELA, Paulo Henrique Gonçalves. Direito Internacional Público e Privado. 6 ed. rev., ampl. e atual. Salvador: Editora JusPodivm, 2014.

TARTUCE, Flávio. Novos princípios do direito de família brasileiro. Jus Navigandi, Teresina, ano, v. 10, 2007. Disponível em: <http://professorpucgoias.edu.br/SiteDocente/admin/arquivosUpload/12035/material/Principios\%20do\%20Dir\%20de\%20Familia.pdf>. Acesso em 30 mai. 2016.

Revista DIREITO UFMS | Campo Grande, MS | v. 2 | n. 1 | p. 153 - 172 | jul./dez. 2016 